\title{
Evaluation of nurse's performance in telemedicine
}

\author{
Avaliação da atuação do enfermeiro em telemedicina \\ Evaluación de la actuación del enfermero en telemedicina
}

Claudinalle Farias Queiroz de Souza'

ORCID: 0000-0003-1541-3089

Dulcineide Gonçalo de Oliveira" ORCID: 0000-0002-8860-1534

Alef Diogo da Silva Santana' ORCID: 0000-0001-8165-6412

Letícia Moura Mulatinho' ORCID: 0000-0001-5662-0733

Mirian Domingos Cardoso' ORCID: 0000-0002-2256-8874

Emanuela Batista Ferreira e Pereira' ORCID: 0000-0003-4665-4379

Jael Maria de Aquino' ORCID: 0000-0001-5095-1662

'Universidade de Pernambuco, Faculdade de Enfermagem Nossa Senhora das Graças. Recife, Pernambuco, Brazil. "Secretaria Estadual de Saúde de Pernambuco. Recife, Pernambuco, Brazil.

How to cite this article: Souza CFQ, Oliveira DG, Santana ADS, Mulatinho LM, Cardoso MD, Pereira EBF, Aquino JM. Evaluation of nurse's performance in telemedicine. Rev Bras Enferm. 2019;72(4):933-9. doi: http://dx.doi.org/10.1590/0034-7167-2018-0313

Corresponding Author:

Claudinalle Farias Queiroz de Souza

E-mail: claudinalle@gmail.com

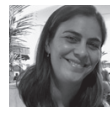

Submission: $08-15-2018$

Approval: 09-29-2018

\begin{abstract}
Objective: Describe the nurse's role in the Telemedicine Program in Cardiology implanted in Pernambuco, Brazil. Methods: Qualitative study, with a target audience of nurses, performed between July and December 2016 at the Emergency Care Units. Data were collected through an online instrument, consisting of open and closed questions, performed with 19 professionals. The data were analyzed through the discourse of the collective subject by QuantiQualisoftware. Results: The sample consisted of 19 nurses, mostly female (80\%), with a mean age of 30 years old. Two central ideas were constructed: nurses' knowledge about the Telemedicine Program in Cardiology; and actions developed by nurses. Also, a flow of the program's assistance was built. Final considerations: The nurse in Telecardiology performs functions of assistance and continuing education of monitoring and training for patients. Descriptors: Nursing Care; Telemedicine; Cardiovascular Diagnostic Techniques; Nursing Informatics; Cardiovascular Diseases.
\end{abstract}

\section{RESUMO}

Objetivo: Descrever a atuação do enfermeiro no Programa de Telemedicina em Cardiologia implantado em Pernambuco, Brasil. Métodos: Estudo qualitativo, com público-alvo de enfermeiros, realizado entre julho e dezembro de 2016 nas Unidades de Pronto Atendimento. Os dados foram coletados por meio de um instrumento on-line, constando de questões abertas e fechadas, realizado com 19 profissionais. Os dados foram analisados através do discurso do sujeito coletivo pelo QuantiQualisoftware. Resultados: A amostra foi composta de 19 enfermeiros, em sua maioria do sexo feminino (80\%), com média de idade de 30 anos. Foram construídas duas ideias centrais: conhecimento dos enfermeiros sobre o Programa de Telemedicina em Cardiologia; e ações desenvolvidas pelos enfermeiros. Ainda, foi construído um fluxo do atendimento do Programa. Considerações finais: $\mathrm{O}$ enfermeiro na Telecardiologia desempenha funções de assistência e educação continuada de monitoramento e de cunho formativo aos pacientes.

Descritores: Cuidados de Enfermagem; Telemedicina; Técnicas de Diagnóstico Cardiovascular; Informática em Enfermagem; Doenças Cardiovasculares.

\section{RESUMEN}

Objetivo: Describir la actuación del enfermero en el Programa de Telemedicina en Cardiología implantado en Pernambuco, Brasil. Métodos: Estudio cualitativo, con público objetivo de enfermeros, realizado entre julio y diciembre de 2016 en las Unidades de Atención de Emergencia. Los datos fueron recolectados por medio de un instrumento on-line, constando de cuestiones abiertas y cerradas, realizado con 19 profesionales. Los datos fueron analizados a través del discurso del sujeto colectivo por el QuantiQualisoftware. Resultados: La muestra fue compuesta de 19 enfermeros, la mayoría del género femenino (80\%), con una media de edad de 30 años. Se construyeron dos ideas centrales: conocimiento de los enfermeros sobre el Programa de Telemedicina en Cardiología; y acciones desarrolladas por los enfermeros. También se construyó un flujo de la atención del Programa. Consideraciones finales: El enfermero en la Telecardiología desempeña funciones de asistencia y educación continuada de monitoreo y de cuño formativo a los pacientes.

Descriptores: Atención de Enfermería; Telemedicina; Técnicas de Diagnóstico Cardiovascular; Informática Aplicada a la Enfermería; Enfermedades Cardiovasculares. 


\section{INTRODUCTION}

The popularization of the Internet has leveraged advances in information and communication technologies (ICT), expanding the health-care services, encompassing web-based applications and thus increasing the availability and use of these technologies in developing countries and in low-income areas ${ }^{(1)}$. In the globalized world, information is made available rapidly and, inherent to it, technology is present, making it necessary to join ICT to process this information in the most efficient way ${ }^{(2)}$.

In the last decades, technology has been incorporated in health management, assistance, teaching and research, especially in nursing, in order to meet emerging care needs in contemporary times $s^{(3)}$. In this perspective, the use of telehealth is an example of distance health care that is in significant growth in many developed countries, with the main intervening factors being the reduction of health care costs and current epidemiological factors, such as aging and the increase of chronic-degenerative diseases ${ }^{(4-5)}$.

Thus, telehealth is defined as the use of modern ICTs for distance activities related to health at different levels of attention, as well as remote access to diagnostic and even therapeutic support resources, thus enabling interdisciplinary interaction among health professionals(6).

Telehealth has been considered an important tool for health professionals, especially nurses, that, in terms of communication, can influence factors such as: interaction time, satisfaction of the subjects involved in this interaction, and limitations related to nonverbal communication ${ }^{(3)}$.

The practice of telehealth represents a new paradigm and proposes to reduce the geographical limits, allowing access to the population that resides far from the urban centers and bringing the orientation of specialized professionals closer to this people, by the follow up professional along with the reference center. For this reason, it has contributed to improve access to health care, the quality of service provided and the effectiveness of many interventions in the area of health care and diagnosis ${ }^{(7-8)}$.

Among many ramifications of telehealth, there is telecardiology, which is one of the most developed areas. This consists of the transmission of cardiovascular parameters, examinations and/or clinical data of patients through the internet and technological tools. In the last ten years, revolutionary progress in telecardiology has been made through the association of ICT, including cell phones and cloud archiving ${ }^{(9-11)}$.

The advantage of telecardiology is to allow remote cardiologists to make timely diagnoses and to propose effective therapeutic strategies for patients in rural areas where this specialty is still not very accessible ${ }^{(9)}$. In addition to reducing the mortality rate of people with acute myocardial infarction, it can reduce the locomotion of the patient's residence to the hospital, or unnecessary transfers between hospitals, since it is a consensus in the literature that the faster the care, the greater the chance of effective interventions ${ }^{(12)}$.

The actions of the nurse in telecardiology are still little discussed in the literature and it is necessary to learn and describe these actions for the improvement and the qualification of these professionals. Nursing care without theoretical support and adequate standardization favors impertinent, negligent, and/or reckless professional practice, which may harm clients, cause ethical problems to professionals, and discredit this professional class before society.

\section{OBJECTIVE}

To describe the nurse's role in the Telemedicine Program in Cardiology, implanted in Pernambuco, Brazil.

\section{METHOD}

\section{Ethical aspects}

This research complied with the recommendations of Resolution 466/2012 of the National Health Council and was approved by the Research Ethics Committee of the University of Pernambuco.

\section{Study type}

A descriptive, exploratory, qualitative approach based on the discourse of the collective subject technique (DCS). In the DCS, there are key expressions and central ideas. Its grouping originates the central ideas, resulting in one or several synthesis speeches, written in the singular form of first person. The "l" symbolizes the collective, that is, the collective manifested through a person ${ }^{(13)}$.

\section{Methodological procedures}

The study was carried out between July and December of 2016, in the Emergency Care Units (ECU), under the supervision of the State Health Department (SHD) and direct management of the Social Health Organizations (SHO) that work in the Instituto de Medicina Integral Professor Fernando Figueira (Imip) ${ }^{(14)}$.

\section{Study scenario}

The Telemedicine Program in Cardiology was implemented in the ECU aimed at developing a support service for diagnosis in cardiology. This service offers electrocardiogram (ECG) reports in digital format transmitted online to a 24-hour Telemedicine Call Center of an outsourced company. The specialist physician will issue the report within a maximum of 20 minutes through the system and, when signs and/or suspicions of myocardial injury are identified, the specialist contacts the requesting unit to provide teleconsultation. This is intended to guide the unit's doctor as to the proper conduct for the patient being treated.

\section{Data Sources}

The study population was composed of nurses who worked in the Telemedicine Program in Cardiology implanted in the ECU. The sample was intentional, with six ECUs and 19 professionals participating. As the ECU coordinator agreed to conduct the research in the unit, the contact of the professionals were provided and they were invited to participate in the research. By agreeing to participate, the link to the data collection instrument was sent via email and WhatsApp and Facebook applications.

\section{Data gathering and organization}

The data were collected through an online instrument built by the authors and formatted on the Google platform; after 
accessing the home page and accepting to participate in the survey, the instrument was made available. It was composed of objective questions to describe the sociodemographic profile of the subjects: date of birth, gender, type of professional formation, time of the last formation; work regime and time in the ECU.

The instrument also contained discursive questions about the nurse's knowledge, purpose and performance in the Program: "If you needed to explain the State Telemedicine Program in Cardiology to a health professional, what would you say?"; "In your opinion, what is the purpose of the Telemedicine in Cardiology at the ECU?"; "Describe your actions developed in the ECU directed to the Program"; "Were the nurses trained to work in the Telemedicine Program in Cardiology of your unit?"; "Describe the flow of patient care by the Program in your unit"; "Considering what you reported on the role of the Nurse in the Program, what would you change?"; "Is there any aspect that makes it difficult for you to assist the patient when using the Program?"; "Would you like to add any further information, suggestions or critique about the Program?"

\section{Data analysis}

Data collected by the online questionnaire were exported to a Microsoft Excel spreadsheet in text format for better visualization and identification of respondents' responses. The nurses were coded to remain anonymous during the reading process to not interfere with data processing. The methodology used in the DCS is complex, so the data treatment was carried out with the support of QuantiQualisoftware. The following steps were taken to construct the discourses: (1) definition of key expressions (E-CH): parts taken from participants' answers that summarized the ideas and speeches, classifying the expressions and identifying their content; (2) identification of central ideas (CI): the expressions identifying the direction of each testimony were signaled, and those that resembled or complemented each other were unified. (3) construction of the DCS: there was a unification of the E-CH present in the nurses' speeches, which had similar $\mathrm{Cl}$ aiming at formulating the related sentences. With the resulting material from the similar $\mathrm{E}-\mathrm{CH}$ and $\mathrm{Cl}$, first-person of the singular form discourses were constructed in which the group speech or collectivity appeared as an individual discourse, in this case, the DCS.

\section{RESULTS}

The sample consisted of 19 nurses, most of whom were female ( $80 \%)$; the mean age was 30 years; $40 \%$ had between one and three years of graduation, $5.2 \%$ over ten years and $42 \%$ had specialization. All of them worked in a CLT regime, and $37 \%$ had more than five years in their respective unit.

From the discourses it was possible to construct two main ideas:

1. The knowledge of nurses about the Telemedicine Program in Cardiology, from the questioning: how can they explain the Telemedicine Program in Cardiology and what is its purpose?

2. Actions developed by nurses in the Telemedicine Program in Cardiology, based on the questioning: describe your actions developed in the ECU directed to the Program.
The first idea elaborated discourses of collective subject (DCS) structured in three themes: technological tool, online communication and diagnosis support.

\section{DCS 1 - Technological tool}

This is a program used by the emergency care units for interpretation and report of the electrocardiograms performed in these units. The electrocardiograms are sent via internet to this service, which, after analysis, sends back the report. It consists of a telemedicine system, from which almost immediate results evaluated by cardiologists are achieved. It is a program developed to aid in diagnoses of coronary syndromes, which facilitates medical diagnoses and also the life of the patient. Telemedicine is an ECG program and, in real time, it is evaluated by cardiologists with the result in approximately five minutes. It helps quickly the possible cardiac complications that need urgency. It is a program that, after the ECG is done, will be sent as an attachment whose report and reading will be done by a team of cardiologists. It is a program that questions physicians about the care of patients with chest complaints.

\section{DCS 2 - Online communication}

Interaction between the specialist in cardiology and the applicant professional. Program in which we perform the electrocardiogram on the patient and send the result by e-mail to the telemedicine cardiologists, who respond with the report. It is a service that provides online care for patients with cardiological needs. An electrocardiogram exam that a cardiologist report via internet. Diagnostic interpretation of cardiological exams by a specialist to untrained professionals. Timely ECG report, since we do not have a cardiologist on duty. Accuracy and speed in the diagnosis of the patient. Access to the evaluation of the specialized cardiologist. Agility in emergency management in cardiology.

\section{DCS 3 - Support for diagnosis}

A tool that assists in the diagnosis of acute myocardial infarction (AMI), with a specialist report. It is an easy-to-use program that facilitates and helps heart disease diagnosis. Since we do not have a cardiologist in ECU, then the purpose is a more accurate diagnosis for the patient. Early diagnosis of severe cardiac diseases, so that the patient can be referred to the reference service. To assist in the definition of diagnosis. Safety and support in the diagnosis of cardiovascular disorders, mainly by medical professionals, since in the ECUs what is offered is basically medical clinic service.

From the second central idea constructed, the discourse of the collective subject was structured in a similar way in three themes: reception, supervision/technical support, and work process.

\section{DCS 1 - Reception}

The patient is classified as having an acute or chronic cardiopathy profile, performs the ECG, and the examination is sent to the physician for primary evaluation, while awaiting, vigilant, the report. Reception and classification of patient risk, performing the ECG exam. Perform the telecardio, explain to the patient what is being done and give $\mathrm{him} / \mathrm{her}$ the result of the exam. Screening and referral of the patient to the ECG room. Direct the client to the exam, collect the initial data and organize the process of having the medical exams and results. 
Evaluate the ECG and, if there is something different, send the person straight to the doctor.

\section{DCS 2 - Supervision/technical support}

Indirect communication with the technician responsible for the equipment, if there is any mistake. Direct the patient to perform an examination/perform the examination if necessary/request urgency for evaluation. We do not have a direct link, because a nurse technician is responsible for performing the exams on the patient. But we get involved in the more bureaucratic parts, such as contacting the responsible telemedicine technician when there is a problem, asking ECG's nurse technician questions as well, whatever it takes. Immediately contact the coordination in case of program malfunction or even defect of the device.

\section{DCS 3 - Working process}

As a nurse, I am also able to perform and send the ECG, and collect the reports. In early identification of suggestive signs and symptoms of heart disease, perform ECG and send it to the Telemedicine Reports Center. Exams made according to the system protocol. We performed the exams and sent them online to the telemedicine. When identified the patient's cardiological risk, they underwent ECG examination which were later sent the cardiologist through the telemedicine system, that sent us back the report. It is important to immediately check the necessity of examination; the rigorous training and attention of the technician who performs the exam; constant observation of the screen for fast action in case of patient's cardiac changes.

Regarding the flow of patient care by the Program in its unit, the nurses described as presented in Figure 1.

\section{DISCUSSION}

Telehealth is an emerging process worldwide, in several specialties, such as cardiology, and at different levels of attention. It is a work process that goes beyond geographic barriers and subsidizes professionals in patient care ${ }^{(15)}$. Within this context, the knowledge and purpose of the Telemedicine Program in Cardiology was discussed by nurses as a component of Telehealth, because they presented it as a technological tool that uses online communication and it is a support for diagnosis.

For the nurse, the tele-nursing segment is recent and its performance needs training in technological resources and in the new work process. For this, this training needs to be started at the undergraduate level in order to follow the current technological era ${ }^{(16)}$.

ICT is increasingly present in professional activities and it is necessary to admit that the professional in this area, due to the needs imposed by technological growth, builds and develops skills and abilities related to attitudes that involve ICT aiming at expanding their professional practice ${ }^{(1,17)}$. However, telehealth is also a continuous and permanent training resource for professionals who did not obtain undergraduate training, because through tele-education it connects and bring health services, reference centers and universities closer ${ }^{(14,18)}$.

The technological tool theme built in this context is justified by the use of the internet, computers and ECG equipment-resources that present good results in health care when used by telehealth ${ }^{(19)}$.

When discussing the effectiveness of the Program, the professionals confirmed that it is resolutive, observing that this Program promotes access to more accurate and effective diagnoses, by sending and receiving reports rapidly, besides the support of a professional expert to follow up on the case.

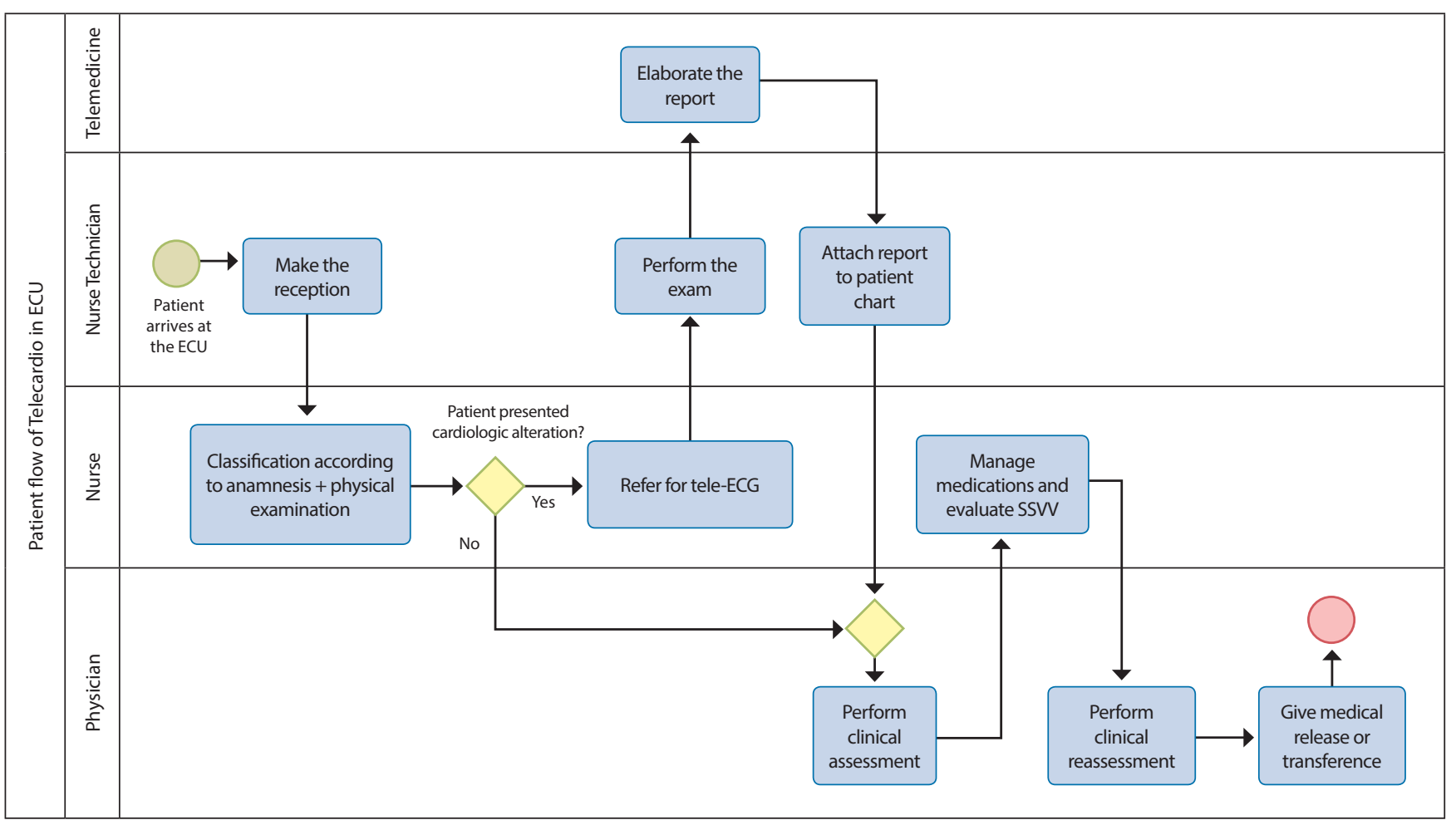

Figure 1 - Nursing care flow in the Telemedicine Program, Recife, Brazil, 2017 
This may enable the nurse to provide early care to the patient, oriented to self-care, prevention of damages and rehabilitation of health, since the delay in the care of patients with cardiac disorders is one of the main causes of death ${ }^{(7,20)}$.

The participants stated the optimization in the care, when identifying electrocardiographic cardiovascular changes in a short time of response of the specialist. The usability of the Program is adequate to the use of non-specialists in the area of technology, since the participants declared that it is a practical, fast and easy to handle system.

The safety and effectiveness of telecardiology in health services aims to be a tool that supports the health system by providing a follow up of patients that fit the profile of aging populations and the incidence of chronic diseases and conditions ${ }^{(19)}$.

The results show the relevance of the communication process in telemedicine. Telehealth communication has been considered as an important instrument for nurses, because it influences factors such as: interaction time, satisfaction of the subjects involved in this interaction, and limitations related to non-verbal communication, change in clinical outcomes and in the therapy proposed ${ }^{(3)}$.

The growth of telehealth in Brazil, as well as the recognition of its importance, has improved access to health care, the quality of service provided and the effectiveness of many interventions ${ }^{(8)}$. For nursing, the incorporation of new technologies in care requires the professionals to know about the impacts of these technologies on their daily lives, so they can ally the technology to the care process ${ }^{(21)}$.

In the context of diagnosis support, the incorporation of technology into nursing practice, such as the use of computerized decision support systems, for example, helps the work for many reasons: it facilitates and makes the decision-making process more agile, subsidizes knowledge in areas where clinical experience is limited, increases safety in problem-solving and ensures quality of care ${ }^{(3)}$.

However, the use of a computerized decision support system can interfere with nursing care by reducing professional autonomy, favoring passivity and inhibiting professional conduct and management, and should not replace nurses' knowledge and skills, but it must be considered as a complement to their activity and their capacity for critical thinking, and the ability to systematize the care ${ }^{(4)}$.

When describing their actions in the Program, three themes were built: reception, orientation/supervision, education/technical support.

The reception is composed of the screening that aims to organize the demand of patients seeking for care in emergency services, identifying those who need fast care in order to be attended properly. The nurse has specific knowledge and skills to define the priority of care, to manage the supply and demand flow of the users in the emergency services, contributing to the reduction of morbidity and mortality ${ }^{(22)}$.

The increase in demand for emergency services has required the increase of technologies in different areas and forms. The specificities of the service provided dynamics in these units in Brazil structured the operation of the ECUs, which are networks facilities of emergency care, of intermediate complexity, with uninterrupted functioning and competence to receive and assist users with clinical picture of any kind ${ }^{(23)}$.

As a strategy of attendance and prioritization of care, the Ministry of Health regulated the National Humanization Policy that proposes guidelines and clinical criteria for classification and evaluation of users, with the implementation of the Reception with Classification and Risk Assessment (RCRA). The RCRA aims to reorganize the care by receiving the user according to the severity of the risk or presented picture, in order to systematize the service so that it is more agile and safe ${ }^{(23)}$.

In addition, the nurse has in his/her routine the conduct of health education by guiding the patient and the nursing team, regarding the training, supervision and maintenance of the service operation. With the new resources implanted in the health practice, the need for updating and qualification by the nurses to act and to provide a quality assistance is notorious. In addition to integrating health actions with the use of telehealth services, culminating in new and valuable technological alternatives that can overcome cultural, socioeconomic and geographical barriers ${ }^{(11)}$.

The first and second ideas were associated to the nurse's routine description in the ECU that relates to capturing the digital ECG by the system, sending it to the specialist and referring the patient to the unit's physician with the report. It presents the team of professionals working with their well-defined functions, in order to aid according to the signs and symptoms suggestive of AMI identified in the physical examination. As well as providing the ECG report with support from the online specialist, to support the medical professional responsible, to define the appropriate conduct.

The actions developed by the nurse and his/her team were described in the discourse through the themes of reception, classification, ECG performance and clinical evaluation. The nurses' classification is intended to collect personal and health data from the patient, from the patient's previous history to the clinical examination, and from there, decide the need for referral to the ECG. Thus, the examination is performed in specific cases and followed by the process of sending and receiving the report, and then with the referral to the doctor of the ECU for clinical evaluation.

The assistance of the nurse in telehealth allows the extension of care to those who need it anywhere that allows its application, since its performance goes through scientific technical knowledge to the capacity to evaluate, lead and care ${ }^{(24)}$.

\section{Study limitations}

The study is limited because it was local, carried out in only one of the Northeastern states, where the characteristics are similar. Future studies may seek to achieve these goals in other centers in the country.

\section{Contributions to the field of nursing}

The topic of study is emerging, being discussed in the Brazilian context, with promising perspectives for nurses in training and inserted in the labor market. This theme expands the scope of thinking of these professionals to seek new work processes and new areas of action for higher quality of patient care.

\section{FINAL CONSIDERATIONS}

The nurse in the Telemedicine Program in Cardiology implanted in Pernambuco knows about its performance in patient care, routine and health education. Although it is a recent work process, it is a relevant subject in professional training since graduation. 


\section{REFERENCES}

1. Sabino LMM, Brasil DRM, Caetano JA, Santos MCL, Alves MDS. Uso de tecnologia leve-dura nas práticas de enfermagem: análise de conceito. Aquichan [Internet]. 2016[cited 2018 Jul 03];16(2):230-9. Available from: http://www.scielo.org.co/pdf/aqui/v16n2/v16n2a10.pdf

2. Camargo AL, Ito M. Utilização das tecnologias de informação e comunicação na área da saúde: uso das redes sociais pelos médicos. J Heal Inf [Internet]. 2012[cited 2018 Jul 03];4(4):165-9. Available from: http://www.jhi-sbis.saude.ws/ojs-jhi/index.php/jhi-sbis/article/view/220/144

3. Barbosa IA, Silva KCCD, Silva VA, Silva MJP. The communication process in Telenursing: integrative review. Rev Bras Enferm [Internet]. 2016[cited 2018 Jul 03];69(4):765-72. Available from: http://www.scielo.br/pdf/reben/v69n4/en_0034-7167-reben-69-04-0765.pdf

4. Barbosa IA, Silva MJP. Nursing care by telehealth: what is the influence of distance on communication? Rev Bras Enferm [Internet]. 2017[cited 2018 Jul 03];70(5):928-34. Available from: http://www.scielo.br/pdf/reben/v70n5/0034-7167-reben-70-05-0928.pdf

5. Dinesen B, Nonnecke B, Lindeman D, Toft E, Kidholm K, Jethwani K, et al. Personalized telehealth in the future: a global research agenda. J Med Internet Res [Internet]. 2016[cited 2018 Jul 03];18(3):e53. Available from: https://www.jmir.org/2016/3/e53/

6. Piropo TGN, Amaral HOS. Telessaúde, contextos e implicações no cenário baiano. Saúde Debate [Internet]. 2015 [cited 2018 Jul 03];39(104):279-87. Available from: http://www.scielo.br/pdf/sdeb/v39n104/0103-1104-sdeb-39-104-00279.pdf

7. Carpintero ERJ, Tavares EC, Souza DCN, Pereira AC, Figueiredo RR, Figueiredo RR, et al. Benefits in using the telehealth: a necessary reflection. Lat Am J Telehealth. 2016[cited 2018 Jul 03];3(2):175-82.

8. Oliveira DG, Frias PG, Vanderlei LCM, Vidal SA, Novaes MA, Souza WV. Análise da implantação do Programa Telessaúde Brasil em Pernambuco, Brasil: estudo de casos. Cad Saúde Pública [Internet]. 2015[cited 2018 Jul 03];31(11):2379-89. Available from: http://www. scielo.br/pdf/csp/v31n11/0102-311X-csp-31-11-2379.pdf

9. Hsieh J-C, Li A-H, Yang C-C. Mobile, cloud, and big data computing: contributions, challenges, and new directions in telecardiology. Int J Environ Res Public Health [Internet]. 2013[cited 2018 Jul 03];10(11):6131-53. Available from: https://www.ncbi.nlm.nih.gov/pmc/articles/ PMC3863891/pdf/ijerph-10-06131.pdf

10. Lazzari C, Genuini I, Gatto MC, Cinque A, Mancone M, D'Ambrosi A, et al. Screening high school students in Italy for sudden cardiac death prevention by using a telecardiology device: a retrospective observational study. Cardiol Young [Internet]. 2017[cited 2018 Jul 03];27(1):7481. Available from: https://www.cambridge.org/core/product/identifier/S1047951116000147/type/journal_article

11. Koivunen M, Saranto K. Nursing professionals' experiences of the facilitators and barriers to the use of telehealth applications: a systematic review of qualitative studies. Scand J Caring Sci [Internet]. 2018[cited 2018 Jul 03];32(1):24-44. Available from: https://www.ncbi.nIm.nih. gov/pubmed/28771752

12. Maldonado JMSV, Marques AB, Cruz A. Telemedicine: challenges to dissemination in Brazil. Cad Saúde Pública [Internet]. 2016[cited 2018 Jul 03];32(sup 2):e00155615. Available from: http://www.scielo.br/pdf/csp/v32s2/1678-4464-csp-32-s2-e00155615.pdf

13. Figueiredo MZA, Chiari BM, Goulart BNG. Discurso do sujeito coletivo : uma breve introdução à ferramenta de pesquisa qualiquantitativa. Disturb Comun [Internet]. 2013[cited 2018 Jul 03];25(1):129-36. Available from: https://revistas.pucsp.br/index.php/dic/article/ view/14931/11139

14. Souza CFQ, Oliveira DG, Santana ADS, Pereira EFB, Cardoso MD. O enfermeiro num Programa de Telemedicina em Cardiologia no Nordeste do Brasil. Ciaiq 2017 [Internet]. 2017[cited 2018 Jul 03];2(2011):582-91. Available from: http://proceedings.ciaiq.org/index.php/ciaiq2017/ article/view/1252/1212

15. Tuckson R, Edmunds M, Hodgkins ML. Telehealth. N Engl Med. 2017;37(16):1585-92.

16. Glinkowski W, Pawłowska K, Kozłowska L. Telehealth and telenursing perception and knowledge among university students of nursing in Poland. Telemed e-Health [Internet]. 2013[cited 2018 Jul 03];19(7):523-9. Available from: http://online.liebertpub.com/doi/abs/10.1089/ tmj.2012.0217

17. Domingues AN, Jesus ITM, Zem-Mascarenhas SH. Informática na educação em saúde e enfermagem: análise dos grupos de pesquisa. J Health Inf [Internet]. 2017[cited 2018 Jul 03];9(1):19-24. Available from: http://www.jhi-sbis.saude.ws/ojs-jhi/index.php/jhi-sbis/article/ view/460

18. Carneiro VF, Brant LC. Telehealth: device of continuing health education within the management of services. Rev Eletr Gestão Saúde [Internet]. 2013[cited 2018 Jul 03];4(2):2365-87. Available from: http://periodicos.unb.br/index.php/rgs/article/view/22960/16483

19. Souza-Jr VD, Mendes IAC, Mazzo A, Godoy S. Application of telenursing in nursing practice: an integrative literature review. Appl Nurs Res. 2016;29:254-60. doi: http://dx.doi.org/10.1016/j.apnr.2015.05.005

20. Gustafsson S, Vikman I, Sävenstedt S, Martinsson J. Perceptions of needs related to the practice of self-care for minor illness. J Clin Nurs [Internet]. 2015[cited 2018 Jul 03]5;24(21-22):3255-65. Available from: http://onlinelibrary.wiley.com/doi/10.1111/jocn.12888/epdf

21. Reierson IÅ, Solli H, Bjørk IT. Nursing students' perspectives on telenursing in patient care after simulation. Clin Simul Nurs [Internet]. 2015[cited 2018 Jul 03];11(4):244-50. Available from: https://www.sciencedirect.com/science/article/pii/S1876139915000146

22. Acosta AM, Duro CLM, Lima MADS. Activities of the nurse involved in triage/risk classification assessment in emergency services: an integrative review. Rev Gaúcha Enferm [Internet]. 2012[cited 2018 Jul 03];33(4):181-90. Available from: http://www.scielo.br/pdf/rgenf/ 
v33n4/en_23.pdf

23. Oliveira JLC, Gatti AP, Barreto MS, Bellucci Jr JA, Goes HLF, Matsuda LM, et al. User embracement with risk classification: perceptions of the service users of an emergency care unit. Texto Contexto Enferm [Internet]. 2017[cited 2018 Jul 03];26(1):1-8. Available from: http://www. scielo.br/pdf/tce/v26n1/0104-0707-tce-26-01-0960014.pdf

24. Santos JLG, Pestana AL, Guerrero P, Meirelles BSH, Erdmann AL. Práticas de enfermeiros na gerência do cuidado em enfermagem e saúde: revisão integrativa. Rev Bras Enferm [Internet]. 2013[cited 2018 Jul 03];66(2):257-63. Available from: http://www.scielo.br/pdf/reben/ v66n2/16.pdf 